\title{
Men and machines ${ }^{1}$
}

\author{
N. H. MARTIN
}

Over 40 years ago, a distinguished physician said, 'in the department of diagnosis early specialization and the advent of numerous physical and chemical methods which at first promised to enhance the science and accuracy of clinical study, have brought disappointment in their train, have hampered the natural evolution of common observation and commonsense, and have fostered faulty methods and uncritical attitudes.' If Gilbert Ryle were alive today, I fear he would have little to retract.

Professor Joll recently embellished the old saw that 'war is too serious a matter to be left to generals' with the comment that 'peace is certainly too serious a matter to be left to professors and computers'. Listening to these words I thought, 'and medicine too', for the care of the sick is the care of individual human beings with all their hopes and fears. However, we are just over 10 years away from George Orwell's 1984, and, at the rate we are going, we should achieve this target with ease.

\section{The Organization of Pathology}

Pathology as an independent discipline established itself, I suppose, in the great teaching hospitals somewhere about the middle of the last century. It centred principally on the teaching of morbid anatomy and microbiology, or, as it was then called, bacteriology. The Pathological Society founded in 1906 was the focal point and its papers indicate what a keen interest there was in experimental pathology. Even then haematology and biochemistry and their application to medical problems were steadily establishing their position. By 1927 when this association was founded, the four areas of pathology which could be mobilized to help physicians and surgeons were well established, and the Association's business was to bring that assistance to doctors throughout the country outside the immediate range or influence of the teaching hospitals. The clinical pathologist, as the name implies, was concerned with the problem 'at the bedside'.

The National Health Service has been with us 25 years. With its formation the pressures on the District

\footnotetext{
${ }^{1}$ The Dyke Foundation Lecture delivered at the meeting of the Association of Clinical Pathologists held at Imperial College, London, 21 September 1973.
}

Hospital Pathology Services mushroomed immediately and alarmingly. The demands have continued to expand steadily since. From 1955 onward your Association fought a vigorous campaign to persuade the Ministry of Health and the regional boards to expand existing facilities and to provide adequate facilities and space for further expansion for the four main pathological disciplines in all new hospitals they were building, or proposed to build. Building notes were constantly revised but with work loads increasing at a yearly average of 10 to $15 \%$, it was not surprising that any place tended to be outdated by the time the premises were put into use. Alas, it seemed regularly to be a matter of 'too little too late'. (May I say that my own experience was that the regional board on which I served was always sympathetic.) When you are building a hospital, $\varnothing$ there are many conflicting priorities and all manner of services which many of us take for granted and rarely inspect. There are also architects who, while they accept the functional aspect of a hospital, would wish to make the final product reasonably attractive, the budget and space permitting. As a patient and visitor, I'm sure they have a point.

The special circumstances of the late war produced two developments in the relationship of pathological services to the community that because of their unquestioned value have stayed with us ever since.

The first is the Public Health Laboratory Service. It is a lasting tribute to its founder, Sir Graham Wilson. I hope in due course his bicycle, suitably inscribed, will be enshrined at the head offices of the organization.

The second is the National Blood Transfusion Service which had its origins in the organization at Bristol under Sir Lionel Whitby. One only has to examine the problems of the blood service complex in the United States to realize what a boon our British service is to us.

Apart from these two nationally integrated services, our pathological laboratories have been part of the organization of the larger hospitals throughout the various regions, each laboratory servicing smaller laboratories geographically near them. Of course there is constant interchange between pathologists but each individual remains a member of the hospital staff and has close daily contact with other 
members of the staff. This is as it should be for full value to be obtained from these services. The formation of a limited number of oncological centres about the country will in no way jeopardize this relationship. Indeed it should be of great value to morbid anatomists faced with the identification of rare tumours or of common tumours presenting in unusual form. But the tentative talk of the formation of 'cold laboratories', where the weight of routine clinical chemistry might be concentrated, is a different matter. It is the type of organization that can be argued most cogently at central committees remote from the site of action. Imagination boggles at the thought of vast institutes packed with wonderfully sophisticated machinery, blood samples flowing in, in endless streams, and data sheets flowing out. But to what end. The organization and value of such laboratories requires very careful scrutiny before they are accepted as justifying the cost of their installation.

\section{Automation}

With the rapidly increasing work load, especially in chemical pathology and haematology, it was inevitable that the means of improving the output per man should be examined. These two fields lend themselves to such inspection because much of their primary data can be presented in numerical form. In 1957 Skeggs developed and tested a continuous flow analytical system which was marketed with enthusiasm and vigour by the Technicon Corporation. The system worked and was well publicized. It was not surprising, therefore, that it was taken up by hard-pressed chemical pathologistsand haematologists all over the world. It is a guess, but I would think that 60 to $70 \%$ of automated equipment in our bigger district hospitals is of this type. However, new machines are in process of development and refinement, notably the Vickers here, and the Aga from Sweden. These may outpace the AutoAnalyzer in their capacity.

But automation of certain movements has been an accepted exercise in big chemical laboratories for scores of years. Automatic balances, automatic apparatus for titrations of every sort, automated spectrophotometry and flame photometry were all with us long before Skeggs perfected his analyzer. The substantial difference in the Skeggs technique was that it was designed to automate complete analytical procedures, particularly those in demand in medicine. In consequence analytical procedures tended to be adapted to the machine. On occasion this may result in inferior analytical methods being employed to the detriment of the information we are trying to obtain. Moreover, new analytical proced- ures which have valuable clinical consequences may be slow of adoption because of difficulties in adapting them to the existing automated framework. With the development of multichannel machines of increasing size, we can from a single specimen liberate a flood of data, much of which may have little relevance to the immediate problem and may even confuse our clinical colleagues and so bemuse them that they overlook the relevant in the welter of irrelevant. Some may say, 'Is anything truly irrelevant in the study of a patient?' In practical terms I think it can be. Moreover the data from a single specimen only represent the situation at a moment in time, and, if biochemical processes are anything, they are dynamic. The fluctuations may be as relevant as the levels. Here arises a difficulty. It is the variance in an automated technical procedure and the range of that variance between one laboratory and another or between two difficult techniques. Cholesterol levels are a case in point. One only has to look at the scatter of values through a number of laboratories to appreciate this. It is not unreasonable to visualize a patient moving from Birmingham to London. The clinician in London, or his adviser, will have to collate the variance between the two centres, both reputable, if he is to form a clear picture of the significance of biochemical changes observed.

Today busy chemical pathology laboratories are talking of throughputs of 500000 and 1000000 in the year and demands are still increasing. It is, I suggest, reasonable to ask what percentage of these analyses contribute to the patient's welfare, either by a substantive contribution or by exclusion. If the latter, it is reasonable to ask in how many instances would a clinician be prepared to exclude a disease process on a single analytical figure. We can all think of some, but not so many as to justify this torrent of data. The Lancet in a recent leader asked, cogently, 'Is more really better?' There has been no reply.

\section{The Computer}

There can be no doubt that the computer has come to stay in medicine as it has in many other fields. If it is to be used effectively, and the cost involved demands this, we must know with precision the quality of the individual items of data we feed in. Numbers may hide inaccurate thinking or inaccurate analysis. Further, we must be able to present on the basis of the material offered a series of correctly formulated questions whose answers will help the user. The implication is that the user has a defined problem, for the computer cannot divine the purpose of the data offered to it.

Programs may need updating regularly. I think it is important, therefore, if delays and errors are to be 
avoided, that the programming staff should be on site, so that they may have regular, free discussions with the pathologist or clinician. Developments in analytical procedures can, and sometimes do, require modifications in the computer program. Such developments are regularly in progress. The computer certainly must not be in the position of delaying worthwhile technical advance.

The newer analytical systems such as the Aga Autochemist, the Vickers MC 300, and the Technicon SMAC include their own process control computers and these systems may have to be linked to other data-processing installations in the area. This may require unexpected adjustment and expense. Today we are bombarded with data, so-called facts. Initially they may present in chaotic array. It is only when within them we perceive some order that they have for us an integrated meaning. In this the computer can save an immense amount of time but it cannot do our thinking for us. It can only test and develop primary ideas thrown up in men's minds. Because an area of pathological observation can be presented in numerical terms it should lend itself readily to inspection by computer but this puts a premium on the origin of the numbers and the method of their deduction.

I have referred to the concept of 'cold chemical laboratories'. With the increasing cost and sophistication of automated equipment, and with work flows rising toward millions, one is bound to take such an organization seriously. But has not the potential of the machine, to some extent, accelerated the demand. I have seen this very situation. A laboratory recently and extensively automated prepared a form laying out the 20 or so different analyses it could offer by automated techniques, asking the clinician simply to tick those he needed. The intention was to save him time. The work flow of that laboratory went up by leaps and bounds. I am sure that was not the intention of the pathologist when he issued the form. The question is then, Would a mammoth computerized centralized system help in the care of the individual patient or the control of disease? I have said already that health and disease are dynamic situations in which the chemistry from isolated samples sheds only transient light.

The problem of the normal level for any individual at a given age is a probability dependent on the scatter of a group of individuals from that age group. For the most part such data have been collected in western urban communities. I doubt if for instance the bilirubin levels we use would be relevant in the upper reaches of the Volta. Over and above this are the levels which lie between the accepted normal and the accepted abnormal which may be of profound significance in one individual but a cause of needless anxiety in another. If we are to use chemical profiles effectively, we must resolve the biological as well as the analytical problems.

\section{Systems Analysis}

Four years ago I described and made a plea for what I called 'system analysis'. If, as I believe, our business is to help the general practitioner and consultant and to supply that help as promptly as we can, I am still of the opinion that grouping of tests to illuminate the adequacy of certain functions is the logical way to set about our work. Moreover, population surveys would, 1 contend, be just as valuable organized in this way, as be some blunderbuss technique involving 20 tests. Dr Franglen, analysing the work flowing through our laboratories, indicated that the range and pattern of investigations called for on any individual patient at any one time peaked quite sharply at five. We then set about working out useful batteries of tests directed at certain biochemical problems common in medicine. So far as possible we avoided overlap of individual analysis, but did not shun them if the particular analysis was cardinal to two different systems. Working with a group of analyses integrated in physiological and biochemical terms, each analysis is assessed within the framework of the group. Moreover, as knowledgee of a particular condition advances fresh forms of $\rightleftharpoons$ analysis can be introduced, and older techniques scrutinized for their relevance and discarded as their usefulness diminishes. So there would be continuous updating orientated to a defined purpose. I believe that with this system programs would be revised with much greater regularity and without the need to interrupt work flow. If this idea is really developed to its logical conclusion, then the different disciplines should come together again, and the haematologist would join the chemical pathologist in the study of iron deficiencies and related anaemias, and the immunologist would join in in the assessment of a patient's immunological competence, a simple immune profile. One need go no further, the idea speaks for itself, and any system that brings us together rather than dividing us is good.

\section{The Nature of the Sample}

Need it be said that the nature of the samples affects the relevance of the information we give to our colleagues. Every morbid anatomist knows with what care he examines a surgical specimen so that he may excise the most relevant portion for histological study. Yet if it is lymph glands he is examining for secondary spread he is in the hands of the surgeon who elected to excise particular glands or groups of 
glands. The haematologist, superficially at any rate, is on firmer ground, for he has developed techniques for examining the bone marrow, as well as the blood, and though the primary fault may be one of absorption, he may well be able to make a calculated guess and then call in the chemical pathologist. When he moves on to the problems of haemolysis and blood clotting, there is an orderly battery of relatively simple tests, and what a splendid array of biochemical and biophysical problems he has before him if he wants to probe into the 'ultimate mysteries'. But how valuable to medicine the probing has been.

The chemical pathologist receives for the most part samples of blood and of urine mingled with faeces and other unattractive material. Rarely does he know whether the blood specimen is fasting or postprandial. It has always seemed to me that much that he examines is one remove away from the origins of the disease. Thus it is in some measure fortuitous that the study of the aminotransferases gives helpful evidence of myocardial damage. I know the massive evidence on which the finding is based. But there must be, indeed there is, a significant lag between the initial damage and the time when the blood level is raised unequivocally. Here is a situation where the progressive study is so important. But how many more enzymes should we be studying, and should we not be extending our studies to the tissues themselves. The cell and the cell surface are foci of vast importance. Already we know that in measuring the viability of skin grafts the measure of their succinic dehydrogenase content is of value. These are the patterns of studies that might well be developed. I have not touched on the significance of the developments in steroid chemistry and the gonadotrophins. These are common knowledge to you all, but are we giving our clinical colleagues sufficient help in that field?

My anxiety is the extent to which existing and projected automatic equipment with all its sophistication absorbs the capital funds allotted to us, and concentrates our attention on certain relatively limited forms on analysis of which the machine is capable, irrespective of its true and fundamental relevance to our continuously advancing knowledge of disease processes to the exclusion of more important biochemical investigations. I am anxious lest we become 'captives of the machine' and lag behind in the real work of the study of disease and of the value of its present and proposed treatment. Think of the information that the techniques of radioimmunoassay may yield and the analytical developments springing from the use of Sephadex.

The flood of information liberated over the past 20 years has made it impossible for any one man to keep abreast of advances in all fields of pathology. The Royal College of Pathologists recognizing this at the outset divided the final examination it superintends into four main divisions, and required that a man need only present himself in one of these divisions. To these must now be added immunology. I do not doubt the wisdom of the decision, but disease processes are not governed by regulations laid down by the Royal College of Pathologists. Their successful treatment may require the intelligent application of information from all five fields. It is probable that the more we specialize the less likely we are able to apply our information wisely, for knowledge is more than information and wisdom beyond both of these

I am delighted that this Association's Council is at last taking steps to widen its membership. I regret that this step was not taken many years ago. The Zuckermann Report and the Ministry's paper on its implementation are with us. But it is we who have got to see that there is real coordination and goodwill. We hear a lot about the discipline of science. Let me assure you not all scientists are disciplined. Like anyone else, to give of their best they have to feel that their job is worthwhile and creative. There is today an enormous surge forward in the biological sciences, and I believe that quite apart from the fascination of the work itself, many working in the field have a deeper stimulus, the good of mankind, though most of us would be too shy to admit it. We must be careful, therefore, that the organization of the work to be done does not reduce men to machine minders. Anyone, as I have, who has visited big automated industries knows the stifling effect that this can have. God forbid that work that has the well being of men at issue should stifle or dull those associated with it.

I started by taking a brief look at the divisions in pathology and I only hope that the necessary divisions of work do not progress unwittingly to cleavage. I think the great need today is for all of us, biological scientists included, to come together to see, in conjunction, what most needs doing and what we can best do to help in the early diagnosis, the cure, and where possible the prevention of disease. This involves too the closest contact with the general practitioner.

We must all face death sooner or later, and though naturally enough we have spent much time studying the lethal diseases, surely it is the crippling diseases that do not kill quickly but destroy the quality of life which might occupy our attention a little more.

I was trained and worked as a pure scientist long before I turned to medicine and so it was not unnatural that in due course I turned through biochemistry to chemical pathology, but on the way I 
spent two years as a morbid anatomist. I have always retained the warmest affection for those who profess this 'cottage industry' of pathology as one illustrious exponent called it. But now sprouting everywhere are the electron microscopes with all the elaborate procedures required to prepare human tissue for their inspection and one is tempted to ask is 'is bigger better'. But I would immediately withdraw my words for here at last there seems a chance that the geography of macromolecular chemistry may be discerned. With suitable labelling we may identify the site within and on the surface of the cell of antigen antibody reactions, specific enzyme sites, and so much more. Many years ago Gowland Hopkins said of biochemistry that 'its essential and ultimate aim is an adequate and acceptable description of the molecular dynamics in living cells and tissues'. With all the recent advances in science, we pathologists of every species should be struggling to understand the disruptions of those 'dynamics' which are the root of disease.

\section{The October 1973 Issue}

\section{THE OCTOBER 1973 ISSUE CONTAINS THE FOLLOWING PAPERS}

SI units in pathology: the next stage D. N. BARON

An outbreak of infantile gastroenteritis due to E. coli 0142 D. H. KENNEDY, G. H. WALKER, R. J. FALLON, J. F. BOYD, R. J. GROSS, AND B. ROWE

Incidence and isolation of Bacteroides species from clinical material and their sensitivity to antibiotics A. A. B. MITCHELL

Intravenous infusions of heparin and penicillins J. JACOBS, DINA KLETTER, E. SUPERSTINE, K. R. HILL, B. LYNN, AND R. A. WEBB

Flavobacterium meningosepticum from cases of meningitis in Botswana and England S. P. LAPAGE AND R. J. OWEN

Clinical, light, and electron microscopy findings in idiopathic haematuria F. ALEXANDER, R. LANNIGAN, AND R. BULL

Detection of fibrinogen antigens with two latex techniques applied to urine concentrates MARIA BENEDETTA DONATI, N. SEMERARO, AND J. VERMYLEN

A batch method for estimating thrombin clottable fibrinogen G. W. FARRELL AND P. WOLF
Serum ferritin concentration and iron stores ir normal subjects G. O. WALTERS, F. M. MILLER, AND M. WORWOOD

Blood zinc in the spinal patient R. G. BURR

Relationship between hepatic morphology and clinical and biochemical findings in morbidly obese patients J. L. MANES, H. B. TAYLOR, AND G. B. STARKLOFF

Prognostic typing in breast cancer B. O. MAEHLE AND F. HARTVEIT

'Sclerosing haemangioma' of the lung: an alternative view of its development A. KENNEDY

\section{Technical methods}

A simple and rapid one-tube method for the determination of urinary delta-aminolaevulinic acid $\mathrm{N}$. SATGUNASINGAM, J. E. BUTTERY, AND G. F. DE WITT

A simple method for the estimation of plasma ammonia using an ion specific electrode N. J. PARK AND J. C. B. FENTON

Capillary-action replicator D. W. R. MACKENZIE

Letters to the Editor

Book reviews

Copies are still available and may be obtained from the PUBLISHING MANAGER, BRITISH MEDICAL ASSOCIATION, TAVISTOCK SQUARE, LONDON, WC1H, 9JR, price $£ 1.05$ 